European Journal of Accounting, Auditing and Finance Research

Vol.8, No. 7, pp.1-17, July 2020

Published by ECRTD-UK

Print ISSN: 2053-4086(Print), OISSN: 2053-4094(Online)

\title{
CORPORATE GOVERNANCE AND COMMERCIAL BANKS' PERFORMANCE IN UGANDA
}

\author{
Charles C. Sendyona \\ Adjunct Faculty, Department of Accounting \& Finance, School of Business, College of \\ Business \& Management Science, Makerere University. \\ Email: sempa1920@gmail.com
}

\begin{abstract}
More than ten commercial banks have collapsed in Uganda in the last two decades due to problems such as frauds, insider lending by dominant shareholders, weak boards of directors, non-performing loans portfolios, and managerial opportunism. This paper aims to investigate the impact of corporate governance on commercial banks' performance in Uganda. The study adopted a survey-based approach to purposively collect data from the respondents of all licensed commercial banks in Uganda at the time of the study. Data was collected using a self-administered research instrument on the most emphasized corporate governance variables of board composition, board size, capital adequacy ratio, and the independent audit committee for the performance of banks. The data quality control was ensured by establishing the internal consistency of the research instrument that resulted in an overall Cronbach's reliability coefficient of 0.78. The data was analyzed using hierarchical multiple regression analysis statistical technique after controlling for bank size and leverage. Using an alpha level of 0.05, the study found that the change in R-squared was $27.9 \%$ with a non-significant change in $F(4,14)=1.64, p=0.219$. Secondly, for the whole model $F(6,14)$ $=1.587, p=0.223$ which signified that was no significant impact of corporate governance on commercial banks' performance in Uganda while controlling for bank size and leverage. In order to improve bank performance in Uganda, the central bank should step up the supervisory and regulatory policies. This would involve proactive strategies such as regular review of corporate governance instruments like the Financial Institutions Corporate Governance Regulations (2005) so as to counteract any new threats to the banking sector which could render these instruments ineffective.
\end{abstract}

KEYWORDS: commercial banks, corporate governance, performance, Uganda

\section{INTRODUCTION}

Bank survival depends on effective corporate governance systems that enhance bank performance, create a stable economic environment, and boost confidence in the banking sector (Jakada \& Inusa, 2014). The impact of corporate governance on firm performance has become a fierce debate in accounting and finance disciplines in recent years due to several corporate governance failures that have adversely affected many world economies. Furthermore, in the last two decades, the stakeholders of the collapsed firms, the regulatory bodies, and the public have been alarmed by the gravity of corporate scandals. Dramatic failures in corporate governance and weak regulatory frameworks have been the major causes of corporate scandals (James \& Joseph, 2015). Due to ineffective corporate governance and weak regulatory frameworks, banks, too, have not survived the wave of corporate failures, and a large number of them have collapsed (Hetes \& Miru, 2010; Onakoya et al., 2014; Liaw, 2012; Marius, 2013). In many economies, commercial banks are viewed as essential institutions that play two critical roles of financial intermediation of public deposits to corporate firms and the provision of a 
Print ISSN: 2053-4086(Print), OISSN: 2053-4094(Online)

payment system which propel the economic growth of countries (Andre \& Vallelado, 2008; Hull, 2010; Kolari, 1996; Lambe, 2014; Samson \& Tarila, 2014). In the banking industry, commercial banking activities are one of the fundamental divisions of banking in the global economy for countries' macroeconomic stability. They involve mobilizing deposits from individuals and corporate organizations and doing business with the mobilized funds. The operations of these banks involve low tolerance for risk and are usually subjected to severe reforms, supervision and regulation by public agencies such as central banks to avoid the crises that have run down banks in the past (Basel Committee on Banking Supervision, 2015; Hetes \& Miru, 2010). The low level of risk tolerance implies that banks have to be cautious while carrying out their business activities to remain competitive and provide a return on investment to their stockholders. For any commercial bank to perform to the stakeholders' satisfaction, it should have an effective corporate governance system in place.

Increasingly scholars have acknowledged that effective corporate governance is necessary for improved bank performance and protection of stakeholders' interests (Andres \& Vallelado, 2008; Basel Committee on Banking Supervision, 2015). Corporate governance uses both internal and external governance mechanisms to monitor management activities within banks (Basel Committee on Banking Supervision, 2015; Onakoya et al., 2012). In recent studies and regulatory frameworks, the most emphasized corporate governance mechanisms in banking include fiduciary responsibilities of the board of directors, the importance of independent oversight of bank management, attachment of high priority to risk management and the need for independent audit function (Basel Committee on Banking Supervision, 2015; Financial Institutions Act (FIA), 2016; Tumusiime-Mutebile 2012).

In the last two decades, there has been a massive failure of banks in Uganda, and the most recent cases being the National Bank of Commerce, Global Trust Bank Ltd, Imperial Bank Ltd., and Crane Bank Ltd. (Bank of Uganda Annual Supervision Reports, 2012; 2014; 2016). Since the early 1990s, ten commercial banks have failed in Uganda and the main reason for bank financial distress and failure in Uganda is due to ineffective corporate governance leading to problems such as frauds, insider lending by dominant shareholders, weak boards of directors, non-performing loans portfolios, and managerial opportunism (Oloo, 2011; TumusiimeMutebile, 2012). Table 1 shows the various banks that failed in Uganda between 1994-2016.

Table 1: Bank Failures Between 1994-2016 in Uganda.

\begin{tabular}{|l|c|}
\hline Bank Name & Year of Failure \\
\hline Teefe Bank Limited & 1994 \\
\hline Trans-Africa Bank Limited & 1998 \\
\hline International Credit Bank Limited & 1998 \\
\hline Greenland Bank Limited & 1998 \\
\hline Cooperative Bank Limited & 1999 \\
\hline Trust Bank Limited & 1999 \\
\hline National Bank of Commercial Limited & 2012 \\
\hline Global Trust Bank Limited & 2014 \\
\hline Imperial Bank (Uganda) Limited & 2016 \\
\hline Crane Bank Limited & 2016 \\
\hline
\end{tabular}

Source: Bank of Uganda Annual Supervision Reports.

This study aims to investigate the impact of the most emphasized corporate governance mechanisms used to monitor management activities in banks on the commercial banks' performance in Uganda. Praptiningsih (2009), and Tumusiime-Mutebile (2012), submitted that these mechanisms fall into three major categories: 1) Internal monitoring mechanisms with 
attributes of leadership structure, board size and board composition. 2) Regulatory monitoring mechanism with a characteristic of capital adequacy ratio. 3) Disclosure/transparency mechanism with an attribute of independent audit committee.

The purpose of this survey-based positivist quantitative study is to explore and understand the impact of corporate governance on commercial banks' performance in Uganda, basing on the fact that bank performance is a function of corporate governance attributes and the regulatory policies (Onakoya et al., 2012). Effective corporate governance of banks is beneficial in the following ways: It translates into a reduction in bank failures, less contagion risks, less emotional torture on the part of the depositors and shareholders, plus improved performance of banks in Uganda. Despite the existence of corporate governance and regulatory frameworks for banks in Uganda, these institutions have not performed to the expectations of the depositors, stockholders, and bank failures have continued to prevail in Uganda. This study, therefore, is an attempt to investigate the impact of corporate governance on commercial banks' performance in Uganda.

\section{Objectives of the Study.}

The main objective of this study is to examine the impact of corporate governance on commercial banks' performance in Uganda. The specific objectives of the study are to:

1. Ascertain how board composition affects commercial banks' performance in Uganda.

2. Examine the impact of board size on commercial banks' performance in Uganda.

3. Evaluate the effect of the independent audit committee on commercial banks' performance in Uganda.

4. Investigate the impact of capital adequacy ratio on commercial banks' performance in Uganda.

5. Evaluate the combined effect of the four attributes of corporate governance on commercial banks' performance in Uganda while controlling for bank size and leverage.

\section{Research Hypotheses.}

The study tested the following null hypotheses to address the objectives of the study:

H10: There is no significant impact of board composition on commercial banks' performance in Uganda.

H20: There is no significant impact of board size on commercial banks' performance in Uganda.

H30: There is no significant impact of the independent audit committee on commercial banks' performance in Uganda.

H40: There is no significant impact of capital adequacy ratio on commercial banks' performance in Uganda

H50: Board composition, board size, independent audit committee and capital adequacy ratio have no significant combined effect on commercial banks' performance in Uganda while controlling for bank size and leverage.

\section{LITERATURE REVIEW}

This section presents a review of literature under the following sub-headings: Theoretical review and empirical review for the study.

\section{Theoretical Review}

The four theories that form the theoretical framework for this corporate governance study are agency theory, resource dependence theory, stakeholder theory and stewardship theory (Nicholson \& Kiel, 2007). The agency theory stipulates the need for the alignment of 
shareholders' (principals) interests with those of management (agents) of a firm (Fama \& Jensen, 1983; Jensen \& Meckling, 1976; Eisenhardt, 1989). The main focus of this theory is to minimize agency problems such as information asymmetry and managerial opportunism (Bektas \& Kaymak, 2009; Bosse \& Phillips, 2016; Jansen \& Meckling, 1976; La Porta, 2000; Miller \& Sardais, 2011; Shleifer \& Vishny, 1997). Furthermore, in countries like Germany and Japan, the focus is on diverse interest groups with a stake in the growth and well-being of firms rather than the purely capitalistic version of the traditional agency theory (Freeman, 1994).

The second theory for the study is the stakeholder theory on which the concentrated ownership system is based. The stakeholder theory views a firm as an entity responsible for a broader group of stakeholders other than shareholders (Lambe, 2014; Maher \& Andersson, 2000). Effective corporate governance aims to protect the interests of individuals within and outside the firm (Fanta et al., 2013). The interest groups of banks include customers, employees, directors, suppliers, other banks, and the general public (Lambe, 2014).

The third theory for the study is the stewardship theory, which describes a system where both the directors and managers work in the best interests of the shareholders (Daily et al., 2003). There are however, cultural differences among different countries, and factors such as gender bias, uncertainty due to political situations, democracy, and freedom of speech along with ethnic groupings differ across developed and emerging economies with differing influence on corporate governance (Chan \& Cheung, 2008).

The fourth theoretical framework for the study is the resource dependence theory (Daily et al., 2003; Nicholson \& Kiel, 2007; Pfeffer \& Salancik, 1978; Wernerfelt, 1984). This theory focuses on the environmental linkages between the firm and outside resources. Wernerfelt (1984) and Dalton et al. (2003) posit that a directors' contribution is the link between the firm and the environment. This linkage helps secure the desired resources, expertise, and governance (Dalton et al., 2003). Lyade (2006) contents that, several approaches to bank regulation and governance such as information disclosure, self-regulation using internal and external audit committees of the board, onsite and offsite supervision and deposit insurance schemes have helped to protect the depositors' funds against losses and are essential for the smooth running of banks.

\section{Empirical Review}

The theoretical foundations of agency theory, stakeholder theory, stewardship theory and resource dependence theory, introduced corporate governance monitoring mechanisms of internal control, disclosure/transparency, and regulation. These mechanisms provide measurable variables of board size, board composition, audit committee independence, and capital adequacy ratio as the most emphasized attributes of corporate governance in banking. The four variables are used in this study to investigate the impact of corporate governance on performance of commercial banks in Uganda. From the review of the agency, resource dependency, stakeholder and stewardship theories as the underlying theories of corporate governance two issues emerge: 1) Effective corporate governance attributes for internal control, disclosure/transparency and regulatory monitoring mechanisms are critical to the performance of banks 2) Corporate governance of banks is different and more important than that of non-financial institutions. Mechanisms such as internal control monitoring, disclosure/transparency monitoring and regulatory monitoring are required to monitor and control the behavior of managers in banks (Andre \& Vallelado, 2008; Baktas \& Kaymak, 2009; Bosse \& James, 2016; Fauzi \& Locke, 2012; Pandya, 2011). 
It is also evident from the literature that the attributes for the internal control monitoring mechanism of board composition and board size are significant determinants of effective board performance (Cadbury Report, 1992; James \& Joseph, 2015; Liang et al., 2013; Mehrotra, 2016; Praptiningsih, 2009). Furthermore, previous empirical studies show that studies involving board composition and bank performance as well as board size and bank performance are mainly investigated using quantitative approaches (Andres \& Vallelado, 2008; Duru et al., 2015; Fanta et al., 2013; James \& Joseph, 2015; Liu et al., 2015; Mehrotra, 2016; Pandya, 2011; Salim et al., 2016; Zhou et al., 2016). The regulatory monitoring mechanism is represented by the capital adequacy ratio attribute, which emphasizes financial regulation to enhance corporate governance of banks (Andres \& Vallelado, 2008; Hwa-Jin, 2016; Onakoya et al., 2012; Umoru \& Osemwegie, 2016). Quantitative approaches have been used in studies involving capital adequacy ratio and bank performance (James \& Joseph, 2015; Praptiningsih, 2009; Umoru \& Osemwegie, 2016). A review of empirical research on the disclosure/transparency monitoring mechanism of corporate governance shows that the independent audit committee attribute is used to guide and monitor banks' performance (Fanta et al., 2013; Kamau et al., 2018). Empirical studies on independent audit committee and bank performance pointed to quantitative approaches as the most used methods of analysis (Bansal \& Sharma, 2016; Fanta et al., 2013). Studies on the control variables of leverage and bank size and firm performance have predominantly been quantitative (Adnan et al., 2015; Aladwan, 2015; Mugweva \& Marime, 2016).

From the empirical review, it emerged that several studies on corporate governance and bank performance have yielded contradictory and inconclusive results and thus the need for further exploration of this topic.

\section{Justification for the Study.}

Most of the recent studies on the performance of commercial banks were conducted in other countries such as Kenya, India, Nigeria, Nepal, and Turkey (Nyamongo \& Temesgen, 2013; Ongore \& Kusa, 2013; Onakoya et al., 2012; Onuonga, 2014; Ozbek, 2015; Pandya, 2011). At the same time, some previous studies on the performance of commercial banks such as the Onuonga (2014) did not address any considerations of corporate governance attributes that impact bank performance. There are studies that have concentrated on corporate governance of banks such as Okiro et al. (2015) and Kamau et al. (2018). However, such studies were not explicitly on banks, but a combination of commercial banks, insurance companies, savings and cooperative societies, microfinance institutions, and non-financial institutions all bundled together in one study and yet the corporate governance of banks is different from that of other institutions (Baktas \& Kaymak, 2009; Caprio \& Levine 2002; Macey \& O'Hara 2003; Tumusiime-Mutebile, 2012). It is important to note that previous studies have produced convincing evidence that corporate governance for banks is different and more critical than that for non-financial firms due to opacity of their balance sheets and the damaging bank failures as a result of negative externalities such as the 2007/2008 global economic meltdown (Bektas \& Kaymak, 2009; Tumusiime-Mutebile, 2012; Haan \& Vlahu, 2016). A particular study on corporate governance and bank performance in Uganda was carried out by Matama (2008), but it suffered from flaws in statistical tools used. All the previous studies have not adequately addressed the impact of corporate governance on commercial banks' performance in Uganda, and this study is expected to fill the existing research gap. 


\section{Variables for the Study}

The focus of this quantitative study is to investigate the impact of the governance variables of board size, board composition, capital adequacy ratio and audit committee independence as independent variables on bank performance as the dependent variable, while

controlling for bank size and leverage. These governance variables are the most emphasized attributes of corporate governance for monitoring bank performance (Adnan et al., 2015; Bektas \& Kaymak, 2009; Praptiningsih 2009; Tumusiime-Mutebile, 2012).

The following model was developed for this study and primary data was collected on the model variables.

Bank performance is a function of corporate governance.

Such that $\mathrm{BP}=\mathrm{f}($ Corporate Governance Attributes $)=\mathrm{f}(\mathrm{BC}, \mathrm{BS}, \mathrm{IAC}, \mathrm{CAR}, \mathrm{BAS}, \mathrm{LEV})$

Where:

$\mathrm{BP}=$ Bank Performance as the dependent variable and is measured by return on assets.

The independent variables for this study are:

$\mathrm{BC}=$ Board Composition measured as the ratio of non-executive directors to the total number of directors on the board.

$\mathrm{BS}=$ Board Size measured as the natural logarithm of the total number of directors on the board.

$\mathrm{IAC}=$ Independent Audit Committee measured as a 1/0 variable where 1 implies presence of independent audit committee and 0 implies otherwise (Dichotomous)

CAR =Capital Adequacy Ratio measured as a bank's capital as a percentage of its riskweighted credit exposure.

BAS $=$ Bank Size measured as the natural logarithm of the total assets.

$\mathrm{LEV}=$ Leverage measured by the proportion of debt to equity in a firm's capital structure.

Therefore, presumed regression model specification for the study is:

$$
B P=\alpha+\alpha_{1} B C+\alpha_{2} B S+\alpha_{3} I A C+\alpha_{4} C A R+\alpha_{5} B A S+\alpha_{6} L E V+e_{i}
$$

Where: $\alpha_{\mathrm{j}}$ is the coefficient of the $\mathrm{j}^{\text {th }}$ governance variable and in the context of this study, every coefficient represents the relative impact of a particular governance variable of the study on commercial banks' performance in Uganda.

$\boldsymbol{\alpha}$ is the intercept term and in the context of this study it represents the expected level of the performance of commercial banks in Uganda in absence of corporate governance mechanisms. ei is the error term for the multiple regression line.

\section{METHODOLOGY}

The research design used in this study falls in the framework of quantitative research methodology where primary data was collected and analyzed using descriptive and inferential statistics. The choice of a quantitative design is justified on the basis that previous researchers who have investigated the impact of corporate governance on bank performance employed quantitative research design. For instance, Praptiningsih (2009) used a quantitative design while studying corporate governance and performance of banking firms in Indonesia, Thailand, Philippines, and Malaysia. Other researchers who employed a quantitative research design include Bektas and Kaymak (2009) while studying the performance of banks in Turkey, Onakoya et al. (2012), while studying the performance of banks in Nigeria and Pandya (2011) who studied the performance of banks in India. A quantitative research design enables the collection and analysis of numerical data using procedures and statistical techniques to examine 
impact among variables (Creswell, 2014; Saunders et al., 2016; Sekaran \& Bougie, 2014). The study adopted a survey strategy to collect primary data from the 21 commercial banks which responded out of a total population of 24 commercial banks in Uganda at the time of the study. In terms of sampling, the selection of the participants was done using purposive sampling techniques since it was only these legal/corporate governance managers who were deemed to satisfy the study requirements by providing meaningful responses for the study. The surveybased approach helped the researcher derive and uncover beliefs that influence the behaviors of the decision-makers regarding corporate governance and performance of banks in an emerging market like Uganda. The research instrument used to collect the primary data was a self-administered questionnaire with a 5-point Likert scale, which was designed by the researcher from the review of the literature and tested for validity and reliability before the actual data collection had taken place. The data from the completed questionnaires were later processed by Microsoft Statistical Package for Social Scientists (SPSS). The quantitative technique that was used to reject or fail to reject the null hypotheses was hierarchical multiple regression analysis. The aim was to establish whether corporate governance had a statistically significant impact on commercial banks' performance in Uganda. The choice for hierarchical multiple regression analysis was based on the fact that there was a need to control possible effects bank size and leverage on the predictive power of the corporate governance variables (Pallant, 2016).

\section{EMPIRICAL RESULTS}

Table 2 presents the Cronbach's coefficient alphas for each subscale and the overall Cronbach's reliability coefficient alpha for the research instrument that was used to collect data for the study. All the Cronbach's reliability coefficients were above .7 implying that the items in the questionnaire reliably measured the desired constructs (Bolarinwa, 2015; Pallant, 2016; Sekaran \& Bougie, 2014).

Table 2: Cronbach's Coefficient Alphas of the Independent Variables

\begin{tabular}{|l|c|}
\hline Study Variable & Reliability Coefficient \\
\hline Board composition & .968 \\
\hline Board size & .727 \\
\hline Audit committee independence & .721 \\
\hline Capital adequacy ratio & .958 \\
\hline Overall Cronbach's alpha & .780 \\
\hline
\end{tabular}

Tables 3, 4, and 5 provide the results for hierarchical multiple regression analysis, model summary, and analysis of variance which were used to accept or fail to accept the null hypotheses $\mathrm{H} 1_{0}, \mathrm{H} 2_{0}, \mathrm{H} 3_{0}, \mathrm{H}_{4}$, and $\mathrm{H}_{5}$ at $5 \%$ level of significance. Before applying hierarchical multiple regression analysis, the researcher ensured that the following underlying assumptions were satisfied.

1) Outliers Assumption- Compared the actual mean $\left(M_{A}\right)$ and the $5 \%$ trimmed mean $\left(M_{T}\right)$ for each variable of the study to ensure that there were no outliers in the data that was collected for the study. The actual and trimmed means for all variables were: Board composition: $\left(M_{A}=\right.$ 3.29; $\left.M_{T}=3.26\right)$, Board Size: $\left(M_{A}=3.18 ; M_{T}=3.20\right)$, Capital Adequacy Ratio: $\left(M_{A}=3.27\right.$; $\left.M_{T}=3.26\right)$, Audit Committee Independence: $\left(M_{A}=3.05 ; M_{T}=3.05\right)$, Bank Size: $\left(M_{A}=3.27\right.$; $\left.M_{T}=3.29\right)$, Leverage: $\left(M_{A}=3.76 ; M_{T}=3.79\right)$, and Bank Performance: $\left(M_{A}=3.91 M_{T}=3.95\right)$. The similarity of each pair of measures signified the absence of outliers in the data set. 
2) Normality Assumption - The Shapiro-Wilk's Test for Normality yielded the following pvalues for the study variables: $B C: p=0.272$, BS: $p=0.503$, CAR: $p=0.382$, IAC: $p=0.139$, BAS: $p=0.058$, LEV: $p=.253$, and BP: $p=0.253$ at 21 degrees of freedom. For ShapiroWilk's test of normality the null hypothesis is usually that the data is normally distributed and should be rejected when a p-values for the study variables are less than an alpha level of 0.05 . For this study all the values were more than 0.05 and the normality assumption was met.

3) Linearity Assumption -Inspection of the scatter plot matrix from the SPSS output revealed a linear relationship between the dependent and independent variables.

4) Homoscedasticity Assumption - The scatter plot revealed a distribution of data points which exhibited a shape that was even from one end to another, signifying non-violation of the homoscedasticity assumption.

5) Multicollinearity Assumption -The collinearity diagnostic tests in SPSS showed that there were no variance inflation factor (VIF) values that were less than 10 and therefore absence of multicollinearity.

Table 3: Hierarchical Multiple Regression Analysis Results.

\begin{tabular}{|c|c|c|c|c|c|c|c|c|c|c|c|}
\hline \multirow{2}{*}{\multicolumn{2}{|c|}{ Model }} & \multicolumn{2}{|c|}{$\begin{array}{l}\text { Unstandard } \\
\text { Coefficients }\end{array}$} & \multirow{2}{*}{\begin{tabular}{|c|}
$\begin{array}{l}\text { Standard } \\
\text { Coefficients }\end{array}$ \\
Beta
\end{tabular}} & \multirow[t]{2}{*}{$\mathbf{t}$} & \multirow[t]{2}{*}{ Sig. } & \multicolumn{3}{|c|}{ Correlations } & \multicolumn{2}{|c|}{$\begin{array}{l}\text { Collinearity } \\
\text { Statistics }\end{array}$} \\
\hline & & B & S. E & & & & $\begin{array}{l}\text { Zero- } \\
\text { order }\end{array}$ & Partial & Partial & TOL & VIF \\
\hline \multirow{3}{*}{1} & (Constant) & 4.448 & .814 & & 5.467 & .000 & & & & & \\
\hline & BAS & .112 & .126 & .198 & .890 & .385 & .234 & .205 & .196 & .982 & 1.018 \\
\hline & LEV & -.210 & .173 & -.269 & -1.211 & .241 & -.296 & -.275 & -.267 & .982 & 1.018 \\
\hline \multirow{7}{*}{2} & (Constant) & 4.098 & 3.13 & & 1.311 & .211 & & & & & \\
\hline & BAS & .046 & .140 & .082 & .331 & .746 & .234 & .088 & .068 & .696 & 1.438 \\
\hline & LEV & -.148 & .250 & -.189 & -.590 & .565 & -.296 & -.156 & -.122 & .412 & 2.427 \\
\hline & $\mathrm{BC}$ & .428 & .273 & .386 & 1.570 & .139 & .349 & .387 & .324 & .702 & 1.424 \\
\hline & IAC & -.622 & .859 & -.254 & -.724 & .481 & -.336 & -.190 & -.149 & .346 & 2.889 \\
\hline & BS & .285 & .255 & .320 & 1.119 & .282 & .369 & .287 & .231 & .520 & 1.922 \\
\hline & CAR & .090 & .333 & .077 & .270 & .791 & -.108 & .072 & .056 & .522 & 1.915 \\
\hline
\end{tabular}

Table 4: Model Summary

\begin{tabular}{|c|c|c|c|c|c|c|c|c|c|}
\hline & & & \multicolumn{3}{|c|}{ Change } & \multicolumn{2}{|r|}{ Statistics } \\
\hline Model & $\mathrm{R}$ & Sq. & $\begin{array}{c}\text { Adjusted } \\
\text { R Sq. }\end{array}$ & $\begin{array}{c}\text { Std. } \\
\text { Error of } \\
\text { Estimate }\end{array}$ & $\begin{array}{l}\text { R Sq. } \\
\text { Chang }\end{array}$ & $\begin{array}{c}\mathrm{F} \\
\text { Change }\end{array}$ & df1 & df2 & $\begin{array}{c}\text { Sig. F } \\
\text { Change }\end{array}$ \\
\hline 1 & $.355^{\mathrm{a}}$ & .126 & .029 & .72422 & .126 & 1.296 & 2 & 18 & .298 \\
\hline 2 & $.636^{\mathrm{b}}$ & .405 & .150 & .67757 & .279 & 1.641 & 4 & 14 & .219 \\
\hline
\end{tabular}

a. Predictors: (Constant), Leverage, Bank size

b. Predictors: (Constant), Leverage, Bank size, Board composition, Capital adequacy ratio,

Board size, Audit committee independence. 
Table 5: Analysis of Variance ${ }^{\mathrm{a}}$

\begin{tabular}{||l|c|c|c|c|c|}
\hline Model & Sum of Squares & Df & Mean Square & F & Sig. \\
\hline Regression & 1.359 & 2 & .680 & 1.296 & $.298^{\mathrm{b}}$ \\
\hline Residual & 9.441 & 18 & .524 & & \\
\hline Total & 10.800 & 20 & & & \\
\hline Regression & 4.373 & 6 & .729 & 1.587 & $.223^{\mathrm{c}}$ \\
\hline Residual & 6.427 & 14 & .459 & & \\
\hline Total & 10.800 & 20 & & & \\
\hline
\end{tabular}

a. Dependent Variable: Bank Performance.

b. Predictors: (Constant), Leverage, Bank Size.

c. Predictors: (Constant), Leverage, Bank Size, Board Composition, Board Size, Capital Adequacy Ratio, Audit Committee Independence.

\section{DISCUSSION OF FINDINGS}

From Tables 4, 5, and 6 the hierarchical multiple regression analysis results are used to guide the discussion of findings for each of the study hypotheses. For all the statistical tests an alpha level of 0.05 was used.

H10: There is no significant impact of board composition on commercial banks' performance in Uganda.

For the board composition variable of corporate governance $\alpha_{1}=0.43, p=0.129$ which implies that is no significant impact of board composition on commercial banks' performance in Uganda and the study failed to reject $\mathrm{H} 1_{\mathrm{o}}$.

H20: There is no significant impact of board size on commercial banks' performance in Uganda.

For the board size variable of corporate governance $\alpha_{2}=0.29, p=0.282$ which implies that is no significant impact of board size on commercial banks' performance in Uganda and the study failed to reject $\mathrm{H} 2_{0}$.

H30: There is no significant impact of the independent audit committee on commercial banks' performance in Uganda.

For the board independent audit committee variable of corporate governance $\alpha_{3}=0.62, p=0.481$ which implies that is no significant impact of the independent audit committee on commercial banks' performance in Uganda and the study failed to reject $\mathrm{H} 3_{\mathrm{o}}$.

H40: There is no impact of capital adequacy ratio on commercial banks' performance in Uganda.

For the capital adequacy ratio variable of corporate governance $\alpha_{4}=0.09, p=0.791$ which implies that is no significant impact of capital adequacy ratio on commercial banks' performance in Uganda and the study failed to reject $\mathrm{H}_{\mathrm{o}}$.

H50: Board composition, board size, independent audit committee and capital adequacy ratio have no significant combined effect on commercial banks' performance in Uganda while controlling for bank size and leverage. 
Modellof Table 3 revealed that, after entering the control variables in step 1 they explained a variance in bank performance of $12.6 \%, F(2,18)=1.296, p=0.298$. In Model 2 of the same table the board composition, board size, capital adequacy ratio, and audit committee independence variables were entered in step 2, and it is evident from Table 4 that the total explained variance in bank performance was $40.5 \%$. Hierarchical multiple regression analysis focuses on the change in R-squared which represents how much of the overall variance is explained by the variables of board composition, board size, capital adequacy ratio, and audit committee independence after the effects of bank size and leverage were controlled. In this study, the corresponding change in R-squared was 27.9\% as indicated in Model 2 of Table 4 with a non-significant change in $\mathrm{F}(4,14)=1.64, \mathrm{p}=0.219$. This implied that when all the variables were taken into account, they explained an additional $27.9 \%$ variation in bank performance when the effects of bank size and leverage were statistically controlled for. From Table 5, F $(6,14)=1.587, \mathrm{p}=0.223$ which implies that for the model as a whole there was no significant combined effect of board composition, board size, audit committee independence, and capital adequacy ratio on commercial banks' performance in Uganda and the study failed to reject $\mathrm{H}_{0}$. Basing on the above evidence the hierarchical multiple regression model of the combined impact of the independent variables on commercial banks' performance in Uganda cannot be formed. This outcome implies that board composition, board size, audit committee independence, and capital adequacy ratio have no significant combined impact on commercial banks' performance in Uganda while controlling for bank size and leverage. The study failed to reject $\mathrm{H} 5_{0}$.

\section{Implications to Research and Practice}

The study did not find any statistically significant impact of all the corporate governance variables on commercial banks' performance in Uganda. It was strange that none of the attributes for the most emphasized corporate governance mechanisms for monitoring and regulating banks revealed a statistically significant impact on commercial banks' performance in Uganda. From the corporate governance point of view, such findings should be an issue of concern to the managers, monitors, and the statutory regulators of the banking sector in Uganda. The results cast doubt on the importance and relevancy of the corporate governance theories of the Anglo-Saxon economies in an emerging market like Uganda embedded with high levels of gender bias, low technological advances, intimidations, political interference, cultural and tribal differences along with appointments based on political party lines, among those who manage, monitor and regulate the banking sector in the country (Chou \& Buchdadi, 2017).

Prior studies from other emerging markets such as James and Joseph (2015) found no statistically significant impact of corporate governance variables on bank performance except for capital adequacy ratio. From the hierarchical multiple regression analysis output for the study, all the variables did not show any statistically significant contribution to the commercial banks' performance in Uganda. However, the coefficients of board composition, board size, and capital adequacy ratio revealed positive signs to bank performance. The audit committee independence is an attribute for the disclosure/transparency monitoring mechanism of corporate governance that ensures sound financial performance and fraud detection (Tumusiime-Mutebile, 2012). One would have expected it to have a unique contribution to the performance of commercial banks in Uganda. Lack of a unique positive contribution by the audit committee independence governance variable to bank performance implies that the respondents' beliefs on this governance variable could have been because such committees have failed to positively contribute to effective corporate governance of commercial banks in Uganda in the past. The recent collapse of Bank of Commerce Ltd, Imperial Bank Ltd, Global 
Trust Bank Ltd and Crane Bank Ltd in Uganda are examples of cases where there has been lack of positive contribution by internal audit committees towards effective corporate governance of banks (Bank of Uganda Annual Supervision Reports, 2012, 2014; 2016). Additionally, there are comparable outcomes from other emerging markets, such as Bansal and Sharma (2016), that internal audit committees do not impact the performance of Indian firms.

Strengthening and regular review of the regulatory frameworks such as the Financial Institutions Corporate Governance Regulations (2005) to counteract the current challenges in the banking sector could be one way of avoiding future bank failures. This strategy calls for more transparency, professionalism, and independence of the Bank of Uganda as the regulator of banks in Uganda.

\section{CONCLUSIONS}

The results and research findings have revealed several outcomes concerning the impact of corporate governance on commercial banks' performance in Uganda. The board composition governance variable has a non-significant impact on the performance of commercial banks in Uganda. Lack of significant impact of the board composition governance variable on commercial banks' performance in Uganda provides evidence that board composition does not contribute to the more effective performance of banks. This finding is inconsistent with the resource dependency theory of corporate governance (Bektas \& Kaymak, 2009; Daily et al., 2000; James \& Joseph, 2015). Therefore, the null hypothesis $\mathrm{H} 1_{\mathrm{o}}$ is not rejected, and it is concluded that there is no significant impact of board composition on commercial banks' performance in Uganda.

Board size is another attribute of corporate governance's internal control monitoring mechanism (Fanta et al., 2013; Kamau et al., 2018). From study hypothesis $\mathrm{H} 2_{\mathrm{o}}$, the findings of the study show that board size has a non-significant impact on commercial banks' performance in Uganda and, therefore, does not make a unique contribution towards bank performance. This finding is contrary to the agency and stewardship theories of corporate governance. Thus, the null hypothesis $\mathrm{H} 2_{\mathrm{o}}$ is not rejected, and it is concluded that there is no significant impact of board size on the performance of commercial banks in Uganda.

The capital adequacy ratio is an attribute of the external corporate governance mechanism for regulating banks. The Basel Committee on Banking Supervision (2015), views capital adequacy ratio as a necessity for prudential regulation and supervision of banks. Based on $\mathrm{H} 3_{\mathrm{o}}$, the findings from the study show that the capital adequacy ratio has no statistically significant impact on commercial banks' performance in Uganda. Lack of a significant impact of the capital adequacy ratio governance variable on the performance of commercial banks in Uganda provides contrary evidence. This is because capital adequacy ratio as an attribute of the regulatory mechanism of corporate governance for banks is an important indicator of effective commercial banks' performance in Uganda (Basel III Accord, 2010). Therefore, the null hypothesis $\mathrm{H}_{3}$ is not rejected, and it is concluded that there is no significant impact of capital adequacy ratio on the performance of commercial banks in Uganda.

The audit committee independence is an attribute of the disclosure/transparency monitoring mechanism of corporate governance, which ensures independence in corporate governance through sound financial reporting and fraud detection (Chou \& Buchdadi, 2017; Cohen et al., 2002). According to the null hypothesis $\mathrm{H} 4$ o, the study results revealed that the independent audit committee does not have a statistically significant impact on the commercial banks' 
performance in Uganda. This could be attributed to the participants' beliefs that some audit committees lack effectiveness in enhancing corporate governance of banks due to lack of auditing expertise by the committee members in which case harmful and unethical activities such as insider dealings, lack of transparency and corruption thrive (Africa Corporate Governance Report, 2016). Therefore, the null hypothesis $\mathrm{H}_{\mathrm{o}}$ is not rejected, and it is concluded that there is no significant impact of the independent audit committee on the performance of commercial banks in Uganda.

The combined impact of all the four governance variables on the commercial banks' performance in Uganda showed a statistically non-significant outcome after controlling for bank size and leverage. Therefore, the null hypothesis $\mathrm{H} 5_{\mathrm{o}}$ is not rejected, and it is concluded that board composition, board size, independent audit committee, and capital adequacy ratio have no significant combined impact on the performance of commercial banks in Uganda after controlling for bank size and leverage.

\section{Recommendations}

The performance of commercial banks in Uganda has disappointed many stakeholders so, to avoid failure in the future, the following recommendations are put forward. People appointed to the board of directors for commercial banks in Uganda should be of diverse backgrounds and experience. For instance, the directors for commercial banks in Uganda should have leadership and negotiation skills, and qualifications in economics, accounting, finance, and banking. They should also be senior technocrats with a clean track record. The Financial Institutions Corporate Governance Regulations (2005) emphasize similar competencies for directors of banks in Uganda. Additionally, such directors should be appointed on merit rather than basing their appointments on religious affiliations, political party lines, or being relatives of the appointing authority.

Furthermore, for the effective performance of commercial banks in Uganda to be a top priority, it is recommended that Bank of Uganda as a regulator and supervisor of banks in Uganda should enforce banking sector policies related to practices that would ensure appropriate board sizes in Uganda commercial banks while taking into account the sizes of the various banks. In this situation, the Financial Institutions Corporate Governance Regulations (2005) would become very handy.

To ensure favourable capital adequacy ratios for commercial banks in Uganda, it is recommended that the Bank of Uganda should be more vigilant in enforcing both the internal and external corporate governance regulatory frameworks for banks. This process would involve full implementation of the Corporate Governance Principles for Banks of the Basel Committee on Banking Supervision (2015). Most importantly, the regulator should adopt proactive strategies towards ineffective bank performance rather than wait for crises. These measures would ensure effective corporate governance and performance of banks in Uganda and lead to favourable capital adequacy ratios, which would enhance banks' resilience.

For the audit committee independence to effectively enhance the disclosure/transparency mechanism of corporate governance of commercial banks in Uganda, it is recommended that such a committee should be constituted in such a way that, the committee members have a good background in financial management and adequate knowledge of the banking sector. 


\section{Future Research Directions}

The current study is limited in the number of governance variables for the internal control, disclosure/transparency, and regulatory monitoring mechanisms of corporate governance. Therefore, one future area of research could be on the same sampling frame of legal/corporate governance managers and population of commercial banks in Uganda but with additional governance variables such as gender diversity among board members, board meetings, board compensation, financial expertise and average board tenure for the internal control monitoring mechanism. While for the regulatory monitoring mechanism, the additional governance variables of loan to deposit ratio and loan loss provision would be considered.

The second future research direction could focus on the fact that, the current study is restricted to commercial banks within the geographical boundaries of Uganda and there is a need for future research to overcome this restriction. Therefore, another potential area of investigation could be corporate governance and performance of commercial banks in the KURT Region (Kenya, Uganda, Rwanda, and Tanzania).

\section{REFERENCES}

Adebayo, M., Bakare, I. A.O, Babatunde, Y. \& Omah, I. (2014) Good Corporate Governance and Organizational Performance: An Empirical Analysis. International Journal of Humanities and Social Sciences, 7(1), 170-178

Adnan, M.A., Rashid, H. M. A., Meera, A.K.M. \& Htay, S.N. (2015) A Panel Data Analysis on the Relationship between Corporate Governance and Bank Performance. Available at https://www.researchgate.net/publication/228823114.

Africa Corporate Governance Report (2016). Available at https://www.afcgn.org

Aladwan, M.S. (2015). The Impact of Bank Size on Profitability "An Empirical Study on Listed Jordanian Commercial Banks." European Scientific Journal, 11(34), 217-236.

Al-Tamimi, K.A.M. \& Obeidat, S.F. (2013). Determinants of Capital Adequacy in Commercial Banks of Jordan: An Empirical Study. International Journal of Academic Research in Economics and Management Sciences, 2(4), 44-58.

Andres, De. P., \& Vallelado, E. (2008). Corporate Governance in Banking: The Role of the Board of Directors. Journal of Banking and Finance 32, 2570-2580.

Bank of Uganda Annual Supervision Report (2012). Available at http://www.bou.or.ug Bank of Uganda Annual Supervision Report (2014). Available at http://www.bou.or.ug Bank of Uganda Annual Supervision Report (2016). Available at http://www.bou.or.ug

Bansal, N. \& Sharma, A.K. (2016). Audit Committee, Corporate Governance, and Firm Performance. Empirical Evidence from India. International Journal of Economics and Finance 8(3), 103-116.

Basel Committee on Banking Supervision (2011). "Basel III: A global regulatory framework for more resilient banks and banking systems" Bank for International Settlements. Available at http://www.bis.org/publ/bcbs189.pdf

Basel Committee on Banking Supervision (2015). Corporate Governance Principles for Banks. Available at http://www.bis.org/bcbs/publ/d328.htm

Bektas, E., \& Kaymak, T. (2009) Governance Mechanisms and Ownership in an Emerging Market: the case of Turkish banks. Journal Emerging Markets Finance and Trade, 45(6), 20-32.

Bolarinwa, O.A. (2015). Principles and Methods of Validity and Reliability Testing of Questionnaires Used in Social and Health Science Researches. Nigerian Postgraduate Medical Journal, 195-201.

Bosse, D. A., \& Phillips, R. A. (2016). Agency Theory and Bounded Self-Interest. Academy of Management Review, 41(2), 276-297. 
European Journal of Accounting, Auditing and Finance Research

Vol.8, No. 7, pp.1-17, July 2020

Published by ECRTD-UK

Print ISSN: 2053-4086(Print), OISSN: 2053-4094(Online)

Cadbury Report (1992), "Corporate Governance". Available at oup.wordpress.com/tag/ Cadbury report/1992/htm.

Caprio, G. \& Levine, R. (2002). Corporate Governance of Banks: Concepts and International Observations. Paper presented at the Global Corporate Governance Forum Research Network Meeting, Mexico City. April, 5.

Chan, A.W.H. \& Cheung, H.Y. (2008). Common Cultural Relationships in Corporate Governance Across Developed and Emerging Financial Markets. Journal of Applied Psychology: International Review, 57(2), 225-245.

Chou, T., \& Buchdadi, A.D. (2017). Independent Board, Audit Committee, Risk Committee, Meeting Attendance Level and Its Impact on Performance. International Journal of Business Administration, 8(3), 24-36.

Cohen, J., Krisnamoorthy, G., \& Wright, A. M. (2002). Corporate Governance and the Audit Process. Contemporary Accounting Research, 19(4), 573-594.

Creswell, J.W. (2014). Research Design: Qualitative, Quantitative, and Mixed Methods Approaches. 4th Edition, New Delhi India. SAGE Publications, Inc.

Daily, C.M., Dalton, D.R. \& Cannella Jr., A.A. (2003) Corporate Governance: Decades of Dialogue and Data. Academy of Management Review 28(3), 371-382.

Duru, A., Iyengar, R. J., \& Zampelli, E. M. (2015). The dynamic relationship between CEO duality and firm performance: The moderating role of board independence. Journal of Business Research, 69(10), 4269-4277.

Eisenhardt, K. M. (1989) Agency theory: An assessment and review. Academy of Management Review, 14(1), 57-74.

Fama, E. F. \& Jensen, M. (1983), "Separation of Ownership and Control", Journal of Law and Economics, 26, 301-325.

Fanta, A.B., Kemal, K.S. \& Waka, Y.K. (2013). Corporate Governance and Impact on Bank Performance. Journal of Finance and Accounting, 1(1), 19-26.

Fauzi, F. \& Locke, S. (2012). Board Structure, Ownership Structure, and Firm Performance: A study of New Zealand Listed Firms. Asian Journal of Accounting and Finance 8(2), 4267.

Financial Institutions Act (2016). Available at http://www.bou.or.ug

Financial Institutions Corporate Governance Regulations (2005). Available at https://ulii.org/ug/legislation/statutory-instrument/2005/47

Haan, J., \& Vlahu, R. (2016). Corporate Governance of Banks: A survey. Journal of Economic Surveys, 30(2), 228-277.

Hetes, R., \& Miru, O. (2010). The Importance of Banks. Implications for the Stability of the Financial System. Annals of Eftimie Murgu University Resita, Fascicle II, Economic Studies, 79-84.

Hull, J. C. (2010) Risk Management and Financial Institutions. Pearson Education, Inc.

1. Hwa-Jin, K. (2016). Financial Regulation and Supervision in Corporate Governance of Banks. Journal of Corporation Law, 41(3), 707-726.

Jakada, B. A., \& Inusa, A. (2014). Corporate Governance: A Strategic Tool for Survival in the Nigerian Banking Sector. Journal of Economic Development, Management, IT, Finance \& Marketing, 6(2), 48-56.

James, B.J. \& Joseph, C. (2015). Corporate Governance Mechanisms and Bank Performance: Resource-Based View. Procedia Economics and Finance 31(2015), 117-123.

Jensen, M. \& Meckling, W.H. (1976) Theory of the Firm: Managerial Behavior, Agency Costs, and Ownership Structure. Journal of Financial Economics, 3, 305-360. 
Jensen, M. (1993) The Modern Industrial Revolution, Exit and the Failure of internal control Systems. Journal of Finance, 48, 831-880.

Johnson, S., Boone, P. D., Breach, A. \& Friedman, E. (2000) Corporate Governance in the Asian Financial Crisis. Journal of Financial Economics, 58: 141-86.

Kamau, G., Machuki, V., Aosa, E. (2018). Corporate Governance and Performance of Financial Institutions in Kenya. Academy of Strategic Management Review, 17(1), 1-13.

Kolari, J. W. (1996). Foreword. Russian \& East European Finance \& Trade, 32(2), 1 - 3.

La Porta, R., Lopez-de-Silanes, F., Shleifer, A. \& Vishny, R. (2000) Investor Protection and Corporate Governance. Journal of Financial Economics 58, 3-27.

Lambe, I. (2014). Appraising the impact of Budgeting and Planning on the Performance of Financial Institutions in Nigeria. Journal of Finance and Accounting, 5(16), 12-26.

Levine, R. (2004). The Corporate Governance of Banks: A Concise Discussion of Concepts and Evidence. Policy Research Working Paper no. 3404, World Bank, Washington, DC.

Liang, N. \& Li, J. (1999). "Board Structure and Firm Performance: New Evidence from China`s Private Firms", China Centre for Economic Research. Available at http://www.ccer.edu.cn/workingpaper/paper/e1999008.pdf

Liaw, K. T. (2012). The Business of Investment Banking. John Wiley \& Sons Inc.

Liu, Y., Miletkov, M. K., Wei, Z., \& Yang, T. (2015). Board independence and firm performance in China. Journal of Corporate Finance, 30, 223-244.

Lyade A.L. (2006). The Impact of Regulation and Supervision on the Activities of Banks in Nigeria (An Assessment of the Role of the CBN and NDIC). Available at www:stclements.edu/grad/gradiyad.pdf

Macey, J.R. \& O'Hara, M. (2003) The Corporate Governance of Banks. Federal Reserve Bank of New York Economic Policy Review 9(1), 91-107.

Maher, M. \& Andersson, T (2000) Corporate Governance: Effects on Firm Performance and Economic Growth. Available at http://dx.doi.org/10.2139/ssrn.218490

Marius, M. M. (2013). The Framework Resulting from the Basel III Regulations. Annals of the University of Oradea, Economic Science Series, 22(1), 1103-1112.

Matama, R. (2008). Corporate Governance and Financial Performance of Selected Commercial Banks in Uganda. A paper presented at CRRC 2008, Queens University, Belfast, 7-9 September, 2008.

Mehrotra, S. (2016). The Nature of Corporate Board Structure and Its Impact on the Performance of USA Listed Firms. IUP Journal of Corporate Governance, 30-45.

Miller, D. \& Sardais, C. (2011). Angel Agents: Agency Theory Reconsidered. Academy of Management Perspectives, 6-13.

Mugweva, R. \& Marime, N. (2016). Bank Specific Factors and Bank Performance in MultiCurrency Era in Zimbabwe. African Journal of Business Management, 10(15), 373-383.

Nicholson, G. J., \& Kiel, G. C. (2007) Can Directors Impact Performance? A case-based Test of Three Theories of Corporate Governance. Corporate Governance: An International Review, 15(4), 585-608.

Nyamongo, E. M., \& Temesgen, K. (2013) The Effect of Governance on Performance of Commercial Banks in Kenya: A Panel Study. Corporate Governance: The International Journal of Effective Board Performance, 13(3), 236-248.

Okiro, K., Aduda, J. \& Omoro, N. (2015). The Effect of Corporate Governance and Capital Structure on Performance of Firms Listed at the East African Community Securities Exchange. European Scientific Journal, 11(7), 504-533.

Oloo, G. (2011). Banking Survey Report, The Best Banks this Decade 2001-2009. Think Business Limited, Kenya, Available at www.bankingsurvey.co.ke 
Onakoya, A. B. O., Ofoegbu, D. I. \& Fasanya, I. O. (2012), "Corporate Governance and Bank Performance: A Pooled Study of Selected Banks in Nigeria", European Scientific Journal, 8(28), 155-164

Ongore, V.O. \& Kusa, G.B. (2013). Determinants of Financial Performance of Commercial Banks in Kenya. International Journal of Economics and Financial Issues 3(1), 237-252

Onuonga, S.M. (2014). The Analysis of Profitability of Kenya's Top Six commercial Banks: Internal Factor Analysis. American International Journal of Social Science 3(5), 94-103.

Ozbek, A. (2015). Performance Analysis of Public Banks in Kenya. International of Business Management and Economic Research 6(3), 178-186.

Pallant, J. (2016). SPSS Survival Manual. 6th Edition Open University Press, McGraw-Hill Education, McGraw-Hill House, Shoppenhangers Road, Maidenhead, Berkshire, England, SL6 2QL.

Pandya, H. (2011). Corporate Governance Structures and Financial Performance of Selected Indian Banks. Journal of Management and Public Policy 2(2), 4-21.

Pfeffer, J., \& Slanick, G.R. (1979). The External Control of Organizations: A Resource Dependence Perspective. Contemporary Sociology, 8 (4), 612-13

Praptiningsih, M. (2009). Corporate Governance and Performance of Banking Firms: Evidence from Indonesia, Thailand, Philippines, and Malaysia. Jurnal Manajemen dan Kewirausahaan 2(1), 94-108

Salim, R., Arjomandi, A., \& Seufert, J. H. (2016). Does Corporate Governance Affect Australian Banks' Performance? Journal of International Financial Markets, Institutions \& Money, 43, 113-125.

Samson, O., \& Tarila, B. (2014). Corporate Governance and Financial Performance of Banks: Evidence from Nigeria. Acta Universitatis Danubius: Oeconomica, 10(2), 216-230.

Sarker, J., Sarker, S. \& Sen, K. (2012). A Corporate Governance Index for Large Listed Companies in India, 1-34. Available at http://www.igidr.ac.in/pdf/publication/WP-2012009.pdf

Saunders, M.N.K., Lewis, P. \& Thornhill, A. (2016) Research Methods for Business Students.7th Edition, Pearson Education Limited, Edinburg Gate, Harlow, Essex CM20 2JE England.

Sekaran, U. \& Bougie, R. (2014). Research Methods for Business: A Skill Building Approach. 6th Edition John Wiley and Sons Ltd. The Atrium, South Gate, Chichester, West Sussex, PO198SQ, United Kingdom.

Shleifer, A., \& Vishny, R.W. (1997). A survey of Corporate Governance. Journal of Finance, 52(2), 737-783.

Sunil, N., \& Santanu, K.G. (2012). Corporate governance attributes, firm characteristics, and level of corporate disclosure: Evidence from Indian listed firms. Growing Science limited 2, 45-58.

Tumusiime-Mutebile, E. (2012). Corporate Governance and Banking Regulation in Uganda. Paper Presented to the Kenya Commercial Bank Board of Directors Retreat, Kampala.

Umoru, D. \& Osemwegie, J.O. (2016). Capital Adequacy and Financial Performance of Banks in Nigeria: Empirical Evidence Based on the Fgls Estimator. European Scientific Journal, 12(25), 295-305.

Velnampy, T. (2013) Corporate Governance and Firm Performance: A Study of Siri Lankan Manufacturing Companies. Journal of Economic and Sustainable Development, 4(3), 228-235. 
European Journal of Accounting, Auditing and Finance Research

Vol.8, No. 7, pp.1-17, July 2020

Published by ECRTD-UK

Print ISSN: 2053-4086(Print), OISSN: 2053-4094(Online)

Wanyama, S. Burton, B. \& Helliar, C. (2009). Frameworks Underpinning Corporate Governance: Evidence on Ugandan Perceptions. Corporate Governance International Review 17(2), 159-175.

Wernerfelt, B. (1984) A Resource-based View of the Firm. Strategic Management Journal $5(2), 171-180$

Zhou, J., Ye, K., Tucker, J. W., \& Chan, K. C. (2016). Board hierarchy, independent directors, and firm value: Evidence from China. Journal of Corporate Finance, 41, 262-279.

Zulkafli, A.H. \&Samad, F.A. (2007) Corporate Governance and Performance of Banking Firms: Evidence from Asian Emerging Markets. Advances in Financial Economics, 12, 49-74. 